\title{
Mechanical Properties of Concrete Incorporating Rice Husk Ash and Wheat Straw Ash as Ternary Cementitious Material
}

\author{
Naraindas Bheel $\mathbb{D}^{1},{ }^{1}$ Paul Awoyera $\left(\mathbb{D},{ }^{2}\right.$ Irfan Ali Shar, ${ }^{3}$ Samiullah Sohu, ${ }^{4}$ \\ Suhail Ahmed Abbasi, ${ }^{4}$ and A. Krishna Prakash ${ }^{5}$ \\ ${ }^{1}$ Department of Civil and Environmental Engineering, Universiti Teknologi PETRONAS, Bandar Seri Iskandar, Tronoh, \\ Perak, 31750, Malaysia \\ ${ }^{2}$ Department of Civil Engineering, Covenant University, Ota, Nigeria \\ ${ }^{3}$ Department of Civil Engineering, ISRA University Hyderabad, Hyderabad, Sindh, Pakistan \\ ${ }^{4}$ Department of Civil Engineering, Quaid-e-Awam University of Engineering, Science and Technology Campus Larkan, \\ Nawabshah, Sindh, Pakistan \\ ${ }^{5}$ Department of Civil Engineering, Anna University, Chennai 600025, India
}

Correspondence should be addressed to Naraindas Bheel; naraindas_20001014@utp.edu.my

Received 6 July 2021; Revised 9 November 2021; Accepted 15 November 2021; Published 29 November 2021

Academic Editor: Yushi Liu

Copyright (c) 2021 Naraindas Bheel et al. This is an open access article distributed under the Creative Commons Attribution License, which permits unrestricted use, distribution, and reproduction in any medium, provided the original work is properly cited.

\begin{abstract}
Over the last decade, there has been a surge in research into possible cement substitute materials in concrete that are environmentally friendly, cost-effective, and socially beneficial. The alternatives include industrial and agricultural wastes, and their potential advantages can be achieved through recycling, repurposing, and renewing processes. With the use of these wastes as additional and replacement materials, significant energy savings and a reduction in cement use can be achieved, which helps to reduce carbon dioxide $\left(\mathrm{CO}_{2}\right)$ emissions in the environment. Therefore, the use of rice husk ash (RHA) and wheat straw ash (WSA) as ternary cementitious material (TCM) in concrete can help reduce the impact on the environment and minimize the use of Portland cement (PC) in the concrete mixture. This research work is performed on the concrete blended with $0 \%, 5 \%, 10 \%, 15 \%$, and $20 \%$ of RHA and WSA as TCM in the mixture. However, the purpose of this experimental work is to investigate the influence of RHA and WSA as TCM on the fresh (slump), physical (water absorption and density), and hardened properties (compressive strength, splitting tensile strength, and flexural strength) and drying shrinkage of concrete. In this regard, a total of 240 concrete samples (cylinders, cubes, and beams) were prepared with $1: 2: 4$ mix proportions at 0.50 water-cement ratio and cured at 7 and 28 days, respectively. Moreover, the workability of green concrete is getting reduced as the quantity of TCM increases in the mixture. Besides, the compressive strength, splitting tensile strength, and flexural strength are enhanced by $12.65 \%, 9.40 \%$, and $9.46 \%$ at $10 \%$ of TCM (5\% RHA and 5\% WSA) on 28 days consistently. Furthermore, the density and water absorption of concrete are reduced with the increase in the dosages of TCM on 28 days, respectively. In addition, the drying shrinkage is reduced with the increase in the quantity of TCM in concrete.
\end{abstract}

\section{Introduction}

The use of concrete has been admired for decades throughout the world [1]. Concrete is man-made material prepared by mixing cement paste with fine and coarse aggregates in designed proportions. The construction industry is highly dependent on this incredible material, and for the time being, there is limited availability of resources that include the binding material, i.e., cement, and aggregates, i.e., coarse and fine. Hence, it is necessary to lessen degradation of natural materials and resources [2] by introducing inexpensive and leftover materials possessing pozzolanic properties with the prospect to substitute conventional materials of concrete [3]. Cement is a costly concrete constituent, and its manufacturing discharges huge quantity of carbon dioxide in the atmosphere [4-6]; one ton of carbon dioxide is released 
while manufacturing one ton of cement [7]. To lessen cost of manufacturing and amount of carbon dioxide, researchers are investigating to replace cement partially with agricultural or industrial discards, i.e., blast furnace slags, wheat straw ash, rice husk ash, fly ash, glass powder, and others [7, 8]. Moreover, concrete production is also liable to be the source of discharge for greenhouse gases in the atmosphere as yearly concrete production is about 1.6 billion tons, which causes the release of greenhouse gases which account for approximately $7 \%$ of total gas emissions [9].

Consequently, effective consumption of solid waste materials in concrete aids in mitigating common problems of environmental pollution, scarcity of raw materials, energy crises, and overhead costs of constructions [10]. Additionally, there could be a major improvement in concrete performance in strength as well as in durability with effective consumption of waste pozzolanic materials, and hence extensive research is being carried out on pozzolans like ashes of sawdust, rice husk, wheat husk, sewage dust, and metakaolin [11], ashes of coconut shell, bottom coal, corn cob $[12,13]$, and so on. Rice husk ash is a solid waste utilized as cementitious material, and bottom coal ash is utilized in replacement of fine aggregate during this research work. RHA, an agricultural by-product [14-16] generally burned in open space, is regarded as the source of air pollution $[17,18]$,because it is regarded as a waste product and proper disposal of such kind of waste is a serious concern as 120 million tons of rice husk is thrown away or burned annually [19-21]. RHA contains about $85 \%$ of amorphous silica which can be employed as cement substituting material [22-25] because of its pozzolanic property, and thus environmental pollution can be minimized to some extent [26-29]. Various research investigations were carried out on concrete blended with $0 \%-20 \%$ of RHA as cementitious material $10 \%-15 \%$ of RHA provides the highest compressive strength of concrete [30]. As size of RHA particle is finer than cement particle, it can improve concrete performance, and it is used as binding material along with cement; therefore, it plays a major role to increase the intertransition zone of concrete [31, 32]. It also makes concrete dense by working as filler material [33].

According to facts and figures given in 2015 by the Food and Agricultural Organization of the United Nations, wheat production per annum was determined as 734.5 million tons [34]. Wheat straw is acquired after harvesting the wheat crop on removal of stubbles, and with production of each $\mathrm{kg}$ of grain, about 1.3 to $1.5 \mathrm{~kg}$ of wheat straw is acquired on average [35]. Worldwide, the annual production of wheat is around 534 million tons, and hence a large quantity of wheat straw is dumped or burned in open space generating environmental pollution. To accommodate such situations, various strategies have been recommended over the burning of wheat straw such as being utilized as fuel for energy production [36], being feed for livestock [37], transforming it as fertilizer, and then utilizing it into the soil for crop productions [38]. But every alternative has few drawbacks [39]. This research recommends incineration as an alternative to disposing wheat straw, while incineration is a process of waste burning in the controlled atmosphere which has the most important advantage that this process lessens the amount of waste by $90 \%$ and landfill sites required for dumping waste $[40,41]$. Therefore, this process is much feasible in urbanized countries like Japan where land available for dumping wastes is too expensive and there is exceptional demand for land. With the incineration process, many developed countries are generating energy [42] which is utilized to further generate electricity [40]. The resulting wheat straw ash possesses pozzolanic property, and thus it is consumed as cement substituting material in construction activities; besides, it releases trivial amount of carbon dioxide in the atmosphere [43]. Moreover, researchers observed that concrete strength increased with the introduction of pozzolanic materials, but due to the low hydration activity of pozzolanic materials such as WSA, strength development in concrete is very slow.

Furthermore, most of the investigations were carried out on concrete blended with WSA and RHA as cementitious material individually, but there is no research work that explored the workability, water absorption, density, compressive strength, splitting tensile strength, flexural strength, and drying shrinkage of concrete incorporating RHA and WSA as ternary cementitious material (TCM) in the mixture. In addition, both RHA and WSA were combined owing to their complementary chemical composition. For instance, RHA has silica as dominant oxide, while WSA has good filling effect in cementitious mixture, but it is not too strong in silica. Thus, combining these TCMs helps in providing pozzolanic effect and filling effect in the developed mixtures. Moreover, this research addresses sustainability issue, and its main focus is to explore the use of RHA and WHA as alternative materials for concrete production, since they are dominant materials in our region. Thus, the research is focused on the beneficial utilization of the materials for construction application.

Therefore, this article summarizes the effect of RHA and WSA as TCM on the fresh property, physical properties, mechanical properties, and drying shrinkage of concrete.

\section{Material and Experimental Program}

2.1. Material. The rice husk was obtained from an agricultural field near Hyderabad, Sindh, and then it was burnt under an uncontrolled temperature arrangement for five hours to convert into rice husk ash (RHA). After obtaining ash, it was passed from sieve \#300 for excluding outsized particles; after that, sieved ash was used in place of cement within mixture. Then, the wheat straw was obtained, and it was burnt under an uncontrolled temperature arrangement for five hours to convert it into wheat straw ash (WSA). After obtaining ash, it was passed from the \#300 sieve for eliminating unwanted materials and then the sieved ash was used as cementitious materials in the mixture. Moreover, the Portland cement (PC) was collected from the local market, and it was employed as binder in mixture. Composition of oxides of PC, WSA, and RHA is presented in Table 1. Furthermore, stones used were crushed for this research work as coarse aggregates (CAs) which possess a size of $20 \mathrm{~mm}$, hill sand was used for experimental study, and fine aggregates used were passed by \#4 sieve. According to ASTM 
TABLE 1: Oxide's percentages and physical properties of PC, WSA, and RHA.

\begin{tabular}{|c|c|c|c|c|c|c|c|c|c|c|}
\hline \multirow{2}{*}{ Materials } & \multicolumn{7}{|c|}{ Oxide components (\%) } & \multirow{2}{*}{ Particles size $(\mu \mathrm{m})[44]$} & \multirow{2}{*}{ Specific surface area $\left(\mathrm{cm}^{2} / \mathrm{gm}\right)[44]$} & \multirow{2}{*}{ Specific gravity } \\
\hline & $\mathrm{SiO}_{2}$ & $\mathrm{Al}_{2} \mathrm{O}_{3}$ & $\mathrm{Fe}_{2} \mathrm{O}_{3}$ & $\mathrm{CaO}$ & $\mathrm{Na}_{2} \mathrm{O}$ & $\mathrm{SO}_{3}$ & LOI & & & \\
\hline RHA & 86.94 & 0.20 & 0.10 & 2.20 & 0.80 & 0.86 & 4.80 & 8.86 & 5980 & 2.23 \\
\hline WSA & 67.34 & 6.44 & 4.36 & 10.60 & 0.47 & 1.85 & 4.20 & 9.13 & 5540 & 2.21 \\
\hline $\mathrm{PC}$ & 20.78 & 5.11 & 3.17 & 60.22 & 0.18 & 2.86 & 2.45 & 18.61 & 3250 & 3.13 \\
\hline
\end{tabular}

C136 [45], aggregate sieve analysis is calculated. The specific gravity of coarse aggregates (CAs) and fine aggregates (FAs) is calculated according to ASTM C127-93 [46] and ASTM C128-93 [47] correspondingly. The ASTM C29-97 [48] code of conduct is used to determine aggregates' bulk density, while the ASTM C127-93 [46] and ASTM C128-93 [47] codes of practice are used to determine water absorption of coarse and fine aggregates, respectively. These aggregates were obtained from Hyderabad, Sindh, and their properties are shown in Table 2, and the sieve analysis curve for coarse and fine aggregates is summarized in Figures 1 and 2 . Moreover, water suitable for drinking was used for mixing as well as curing of concrete.

2.2. Mix Proportions. The mixing process in this investigation followed the standard practices used in conventional concrete mixing, and all of the mixing was done manually. For raw material preparation, PC, aggregates, RHA, WSA, and water were all weighed. The dry mix was first completed by manually mixing PC, aggregates, WSA, and RHA in a mixer until they were uniformly mixed. After that, water was added to the dry mix. The mix was mixed until the wet mixture was changed to a homogenous mixture, and then the workability of fresh concrete was checked immediately. After checking the workability, the fresh mixture of concrete was poured into moulds and left for 24 hours for achieving desired shape and was kept in curing until testing. These concrete specimens were used for physical (water absorption and density) and hardened properties (compressive strength, splitting tensile strength, flexural strength, and drying shrinkage) of concrete blended with TCM0 $(0 \%$ WSA + 0\% RHA), TCM5 (2.5\%WSA+ 2.5\%RHA), TCM 10 (5\% WSA+ 5\% RHA), TCM 15 (7.5\% WSA+ 7.5\% RHA), and TCM20 (10\% WSA $+10 \%$ RHA) in the mixture. In this regard, a total of 240 concrete samples (cylinders, cubes, and beams) were equipped with $1: 2: 4$ mix proportions at 0.50 water-cement ratio and cured at 7 and 28 days, respectively. The mix proportions are mentioned in Table 3.

\subsection{Testing Procedures}

2.3.1. Workability (Slump Test). This test had been performed on overall fresh concrete mixes with different proportions of RHA and WSA as TCM by observing code BS EN 12350-2 [49] in concrete.

2.3.2. Mechanical Properties of Concrete. Water absorption and density of hardened concrete were checked over the specimens made of concrete blended with several
TABLE 2: Aggregate properties.

\begin{tabular}{lcc}
\hline Property & Fine aggregate & Coarse aggregate \\
\hline Fineness modulus (FM) & 2.21 & - \\
Specific gravity $(\mathrm{SG})$ & 2.64 & 2.70 \\
Water absorption $(\%)$ & 1.72 & 1.30 \\
Bulk density $\left(\mathrm{kg} / \mathrm{m}^{3}\right)$ & 1890 & 1569 \\
\hline
\end{tabular}

proportions of RHA and WSA as TCM in concrete as verified by BS 1881 [50] and BS EN 12390-7 [51] techniques on 28 days, correspondingly. However, the compressive strength test was conducted on the cubical specimen with $100 \mathrm{~mm} \times 100 \mathrm{~mm} \times 100 \mathrm{~mm}$ dimensions, and the splitting tensile strength test was conducted on cylindrical specimen with $200 \mathrm{~mm} \times 100 \mathrm{~mm}$ dimensions, blended with various levels of replacement of PC with RHA and WSA as TCM in the mixture by using the BS EN 12390-3 [52] and BS EN 12390-6 [53] code practice consistently. Besides, the flexural strength was tested on beam specimen with dimensions $500 \mathrm{~mm} \times 100 \mathrm{~mm} \times 100 \mathrm{~mm}$, with replacement of PC with RHA and WSA as TCM in mixture under the BS EN 12390-5 [54] code practice. These concrete samples were cured and tested at 7 and 28 curing days. Furthermore, the drying shrinkage test was performed on concrete cylindrical samples with the addition of RHA and WSA as TCM in concrete mixture by using the BS ISO 1920-8 [55] code technique at $5,10,15,20,30,60$, and 90 days, correspondingly. The experimental setup of concrete testing is presented in Figure 3.

\section{Results and Discussion}

3.1. Slump Test. The test performed to measure fresh concrete consistency by addition of WSA and RHA as ternary cementitious material (TCM) is indicated in Figure 4. The optimum value of slump recorded on control mix was $62 \mathrm{~mm}$, and the minimum slump value noted was $24 \mathrm{~mm}$ at $10 \%$ WSA along with $10 \%$ of RHA as TCM in the mixture. It can be perceived that the slump of green concrete is dropped with the addition of WSA and RHA together in a mixture. This drop in slump is due to the high specific surface area of RHA and WSA particles than that of PC as shown in Table 1 which absorb more water as compared to PC while the percentages of RHA and WSA increase in the concrete mixture. Moreover, the $20-24 \mathrm{~mm}$ slump is small for practical application. Therefore, the study suggests the use of plasticizer for improving the workability of the mixture. This research work is linked with Al-Akhras and Abu-Alfoul [56] where slump declined with the increase in dosages of WSA 


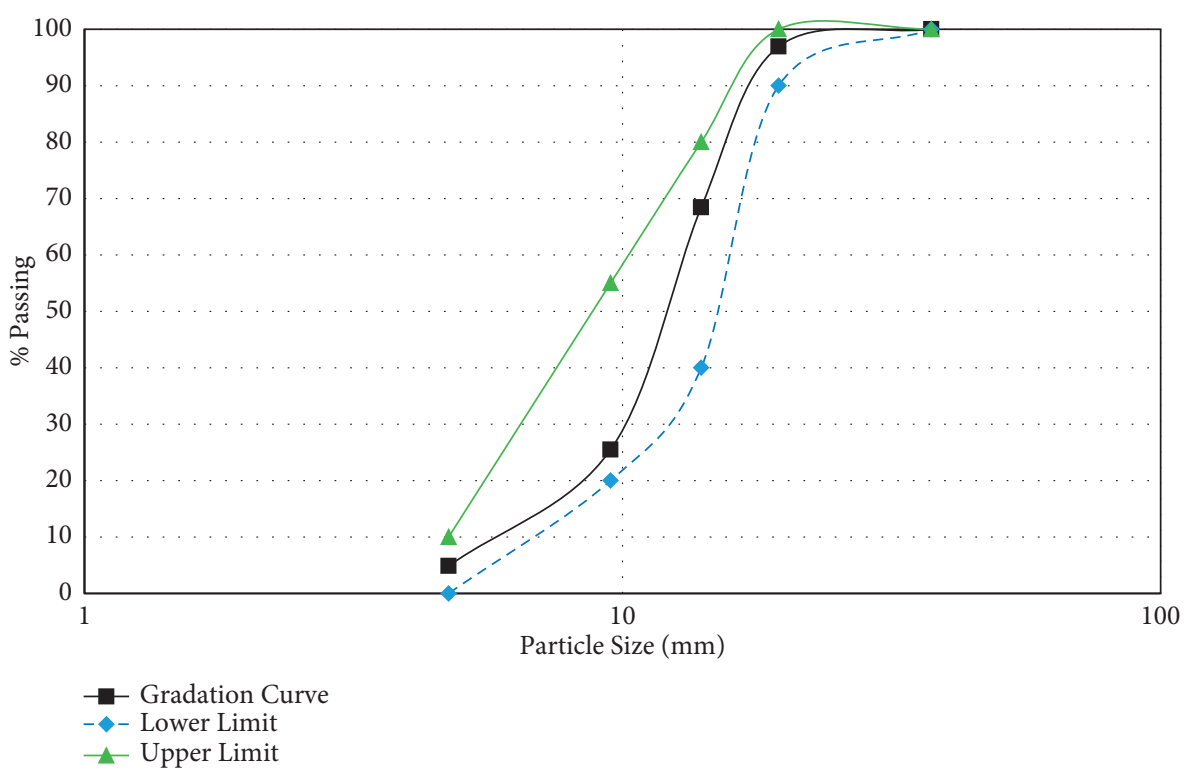

FIgURE 1: Grading curve of coarse aggregates (CAs).

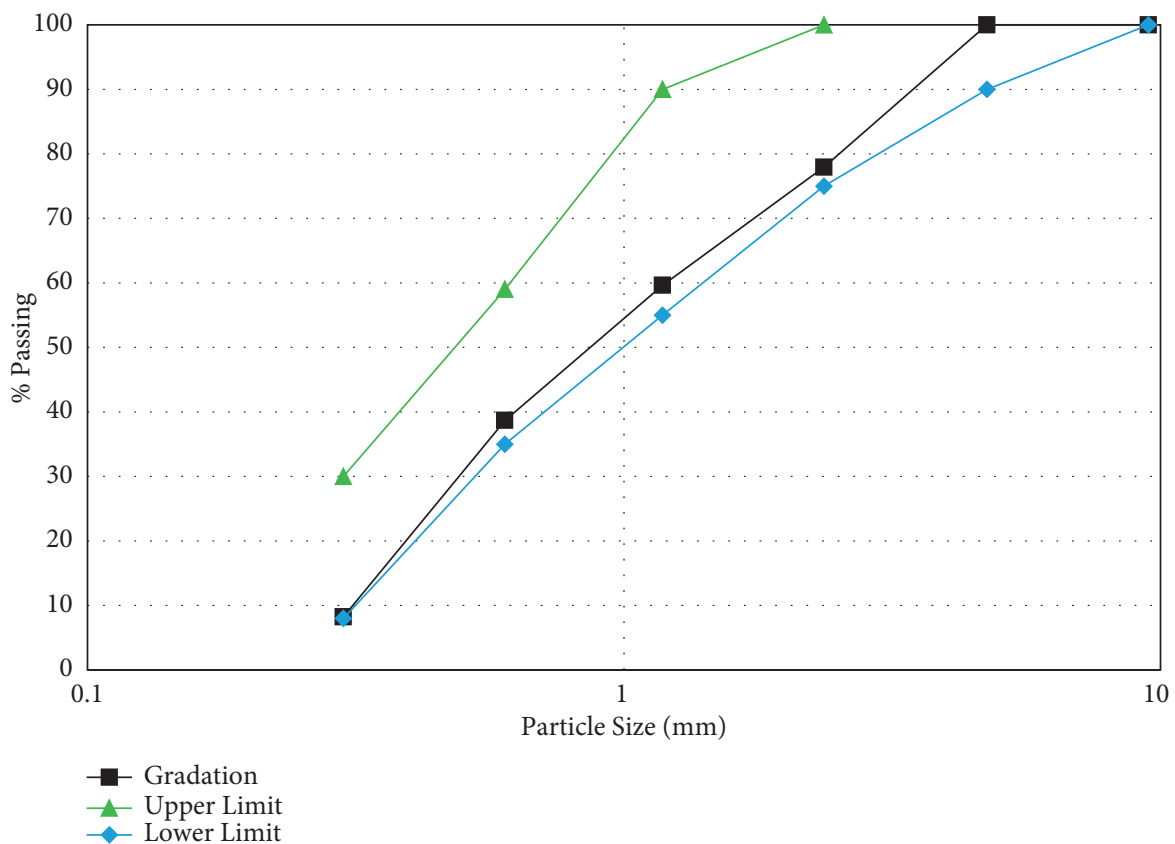

Figure 2: Grading curve of fine aggregates (FAs).

in the concrete. A related research study was carried out by Kurama and Kaya [57] and Adesanya and Raheem [58].

3.2. Density of Concrete. Concrete density using different percentages of WSA and RHA as TCM determined after 28 curing days is presented in Figure 5. However, density of concrete recorded by $2374,2342,2300$, and $2288 \mathrm{~kg} \mathrm{per}^{3}$ at 5\% (2.5\% WSA+2.5\%RHA), 10\% (5\% WSA+5\%RHA), $15 \%$ (7.5\% WSA+7.5\%RHA), and $20 \%$ (10\% WSA+10\%RHA) is lower when compared with control mix. It can be seen that the density of concrete has plummeted as the dosages of
WSA and RHA rise in the mixture. This reduction in density is due to the fact that the specific gravity of WSA (2.21) and RHA (2.23) is lower than that of cement (3.13). This statement was specified in [59] where the density of concrete declined with the increase of dosages of millet husk ash in the mixture at 28 curing days. This comparable investigation has been performed by Raza et al. [60].

3.3. Water Absorption of Concrete. The test performed on hardened concrete mixture by incorporating WSA and RHA as ternary cementitious material at 28 curing days is 
Table 3: Mix proportion of mixture.

\begin{tabular}{lccccccr}
\hline \multirow{2}{*}{ Mix ID } & Mix ratio & PC & Binder (\%) & \multicolumn{2}{c}{ Aggregates (\%) } & Water/cement ratio (\%) \\
& & WSA & RHA & FA & CA & 0.50 \\
TCM0 & $1: 2: 4$ & 100 & 0 & 0 & 100 & 100 & 0.50 \\
TCM5 & $1: 2: 4$ & 95 & 2.5 & 2.5 & 100 & 100 & 0.50 \\
TCM10 & $1: 2: 4$ & 90 & 5 & 5 & 100 & 100 & 0.50 \\
TCM15 & $1: 2: 4$ & 85 & 7.5 & 7.5 & 100 & 100 & 0.50 \\
TCM20 & $1: 2: 4$ & 80 & 10 & 10 & 100 & 100 & \\
\hline
\end{tabular}

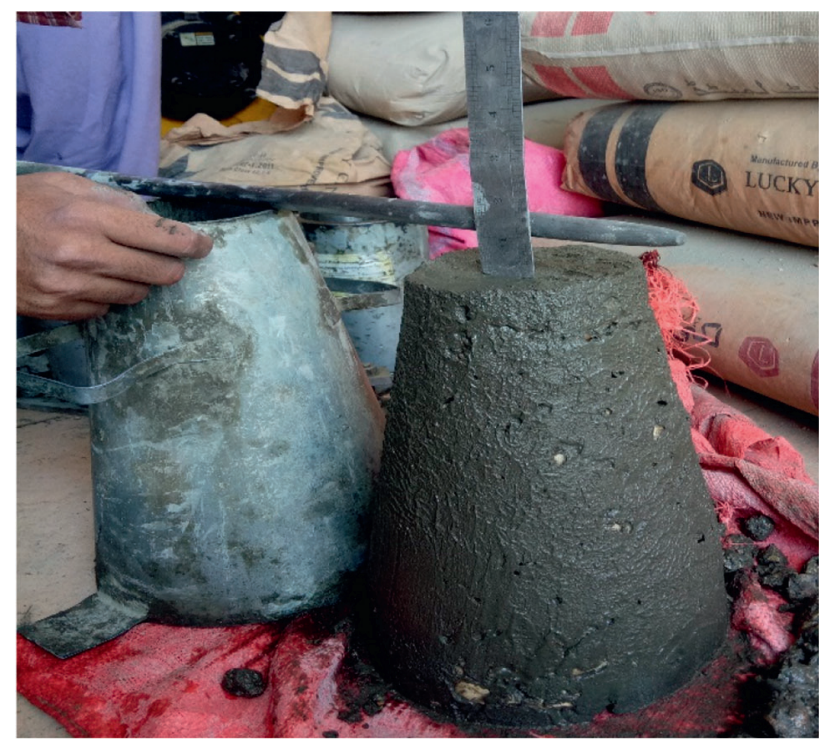

(a)

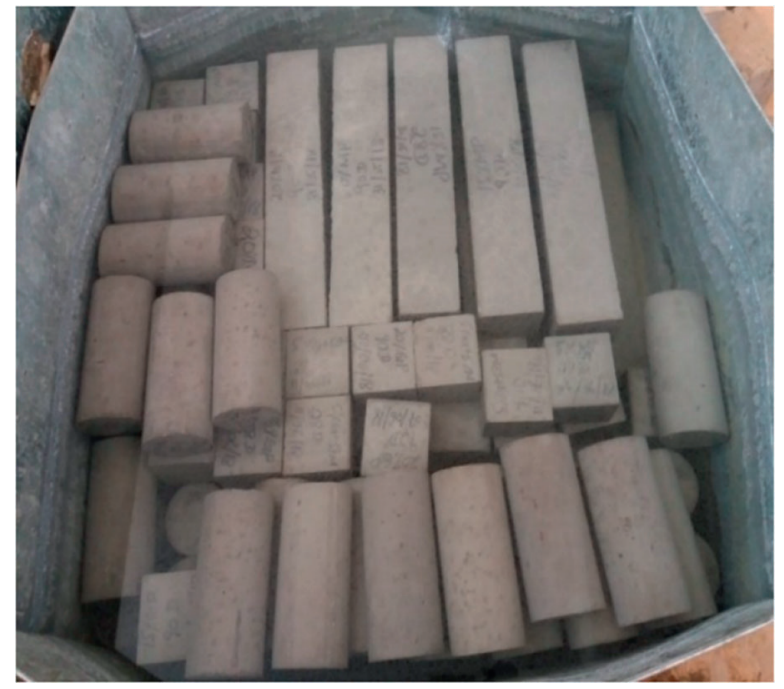

(c)

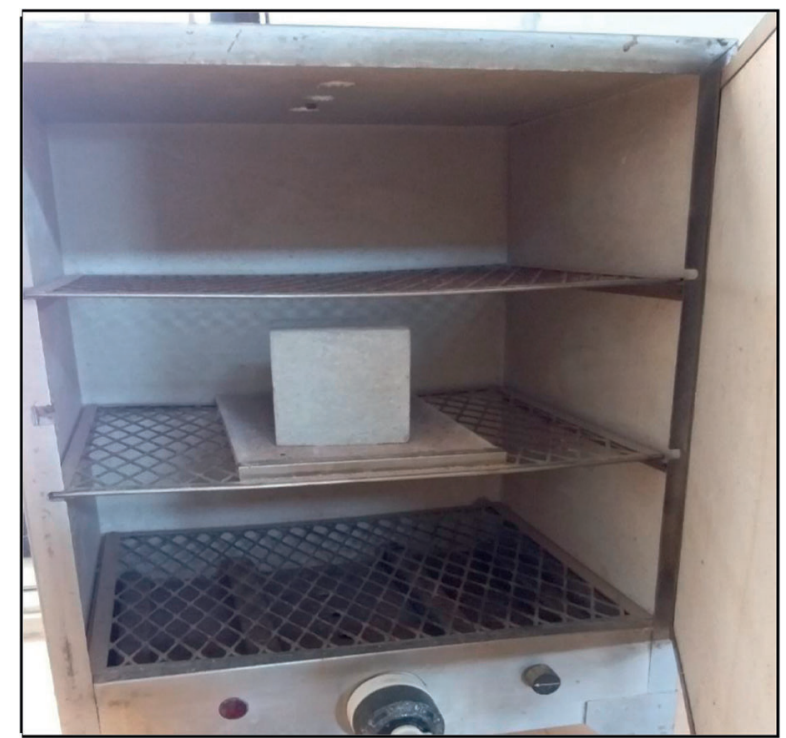

(b)

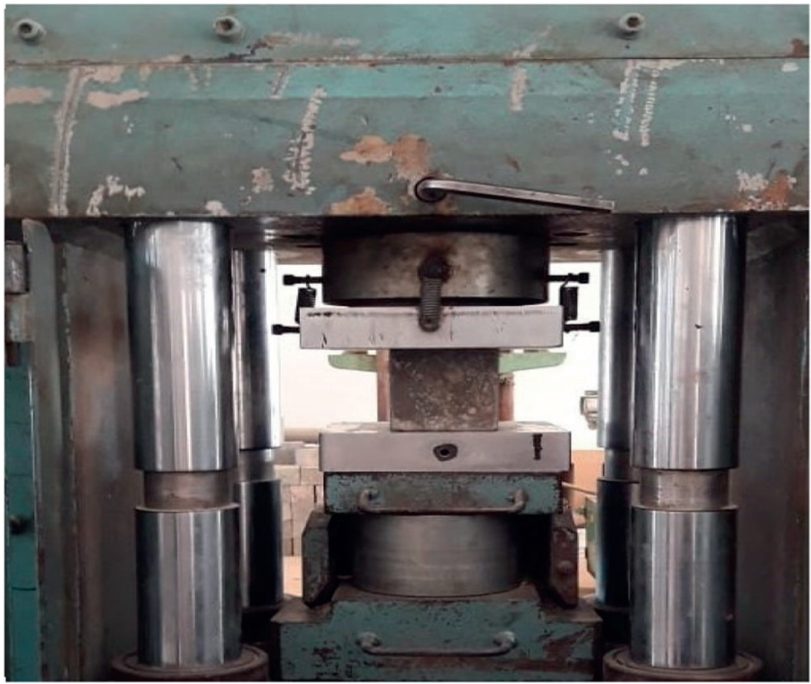

(d)

Figure 3: Continued. 


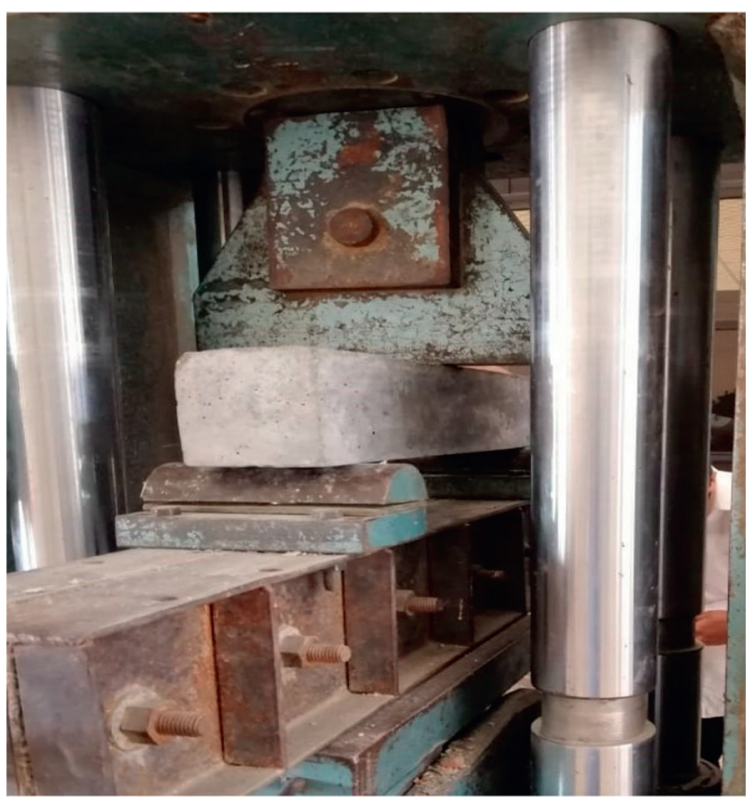

(e)

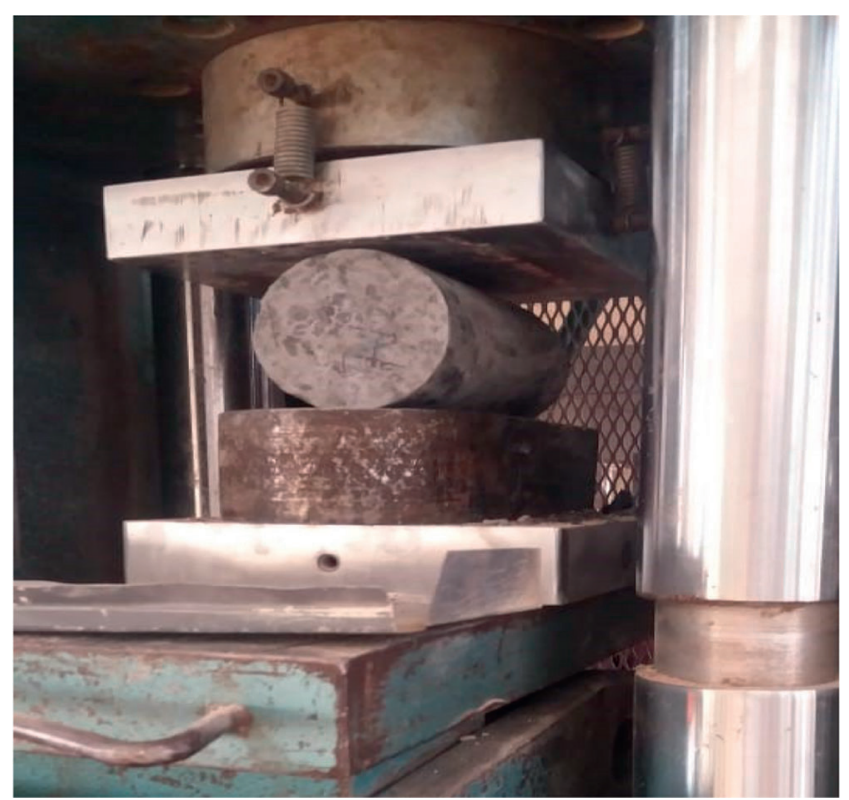

(f)

Figure 3: Experimental setup of concrete testing. (a) Slump test. (b) Water absorption test setup. (c) Water curing tank. (d) Compressive strength test. (e) Flexural strength test. (f) Splitting tensile strength test.

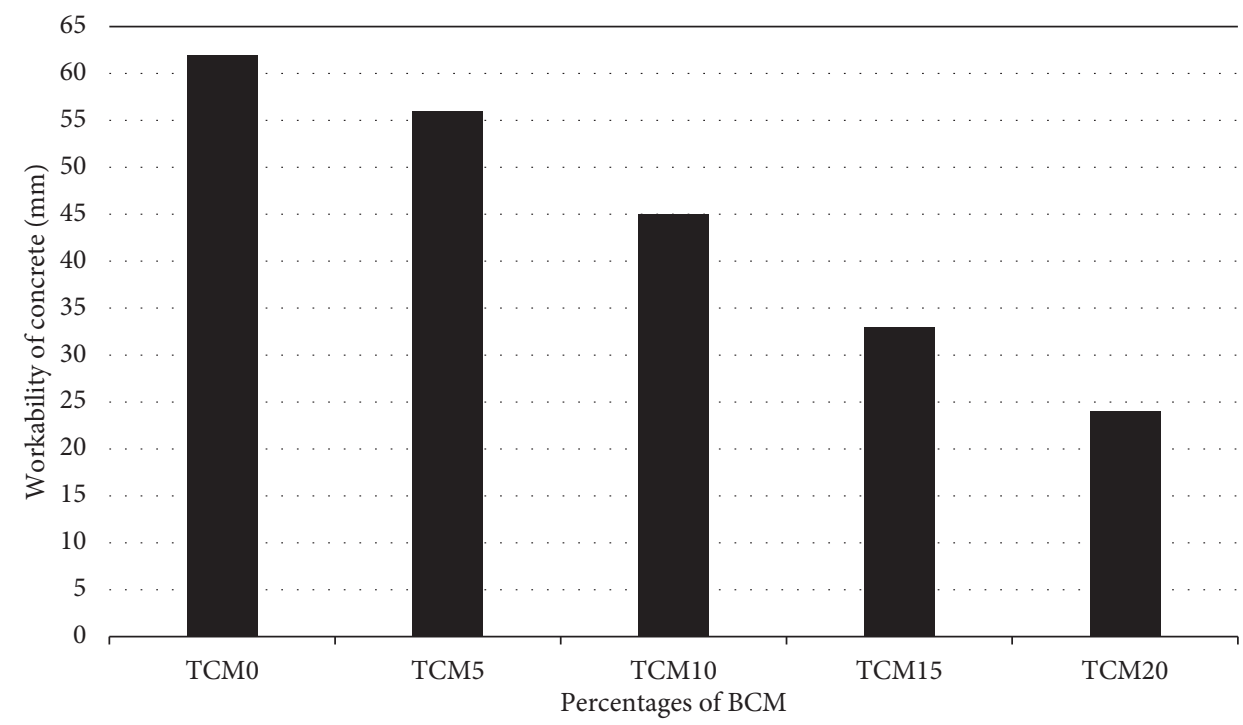

FIgURE 4: Slump test of green concrete.

indicated in Figure 6. The maximum water absorption is noted as $3.75 \%$ at control mix, and the minimum value is noted as $1.88 \%$ at $10 \%$ WSA and $10 \%$ RHA as TCM in concrete mix at 28 days. The outcome is that the water absorption of hardened concrete is reduced with the addition of WSA and RHA together in the concrete mixture. This decline in water absorption is due to the size or finest particles of RHA and WSA compared to PC as shown in Table 1 which seals the remaining micropores left by other constituents of concrete while the percentages of RHA and WSA increase in the concrete mixture. This investigation work is related to Auta et al.'s study [61] where water absorption declined with the increase in incorporation of millet husk ash in concrete. This comparable investigation has been performed by Dharani et al. [62] and Raza et al. [60].

3.4. Compressive Strength of Concrete. The test performed on cubical specimen made with concrete by addition of WSA and RHA as TCM is indicated in Figure 7. The highest compressive strength calculated is $25 \mathrm{MPa}$ and $30.42 \mathrm{MPa}$ at $5 \%$ of WSA along with $5 \%$ of RHA, and the smallest strength is recorded as $19.2 \mathrm{MPa}$ and $23.3 \mathrm{MPa}$ while utilizing $10 \%$ of 


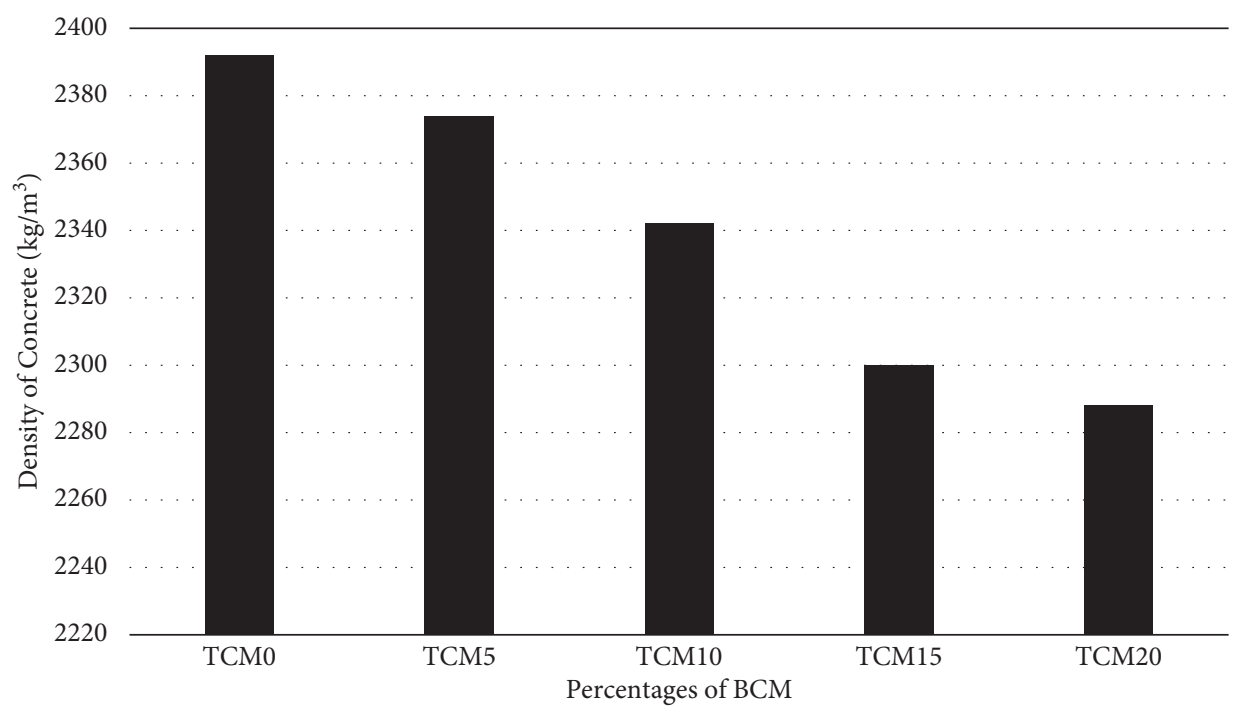

Figure 5: Density of concrete.

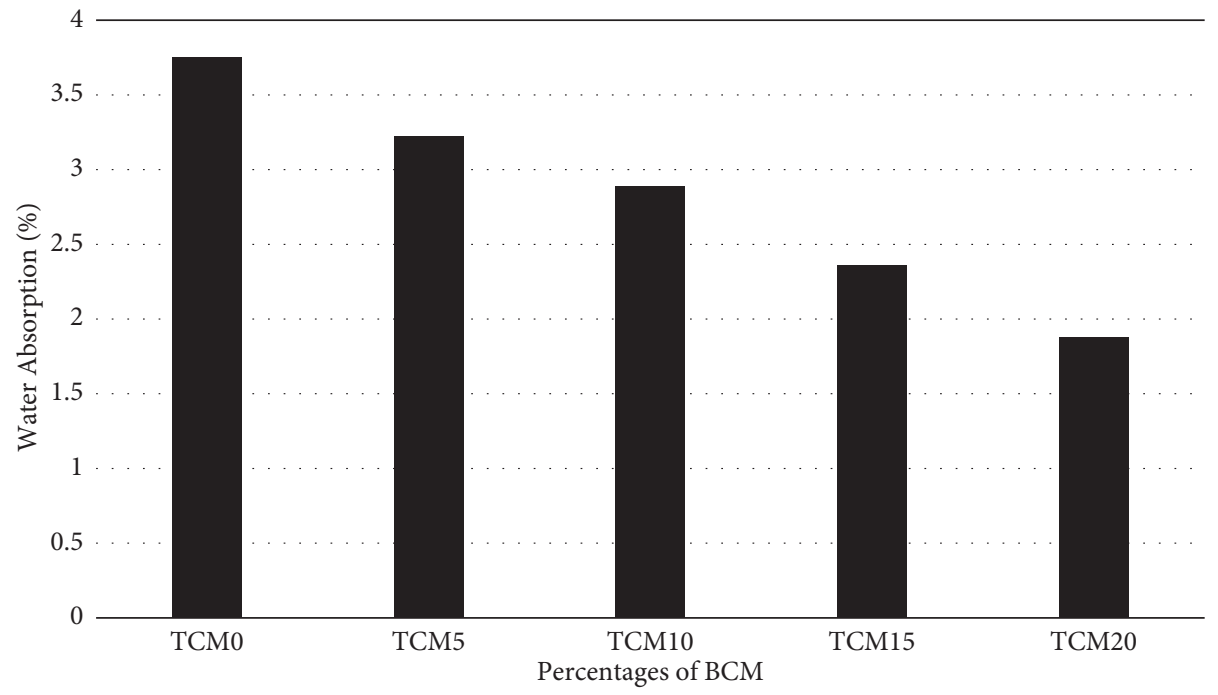

FIgURE 6: Water absorption of concrete.

WSA along with $10 \%$ of RHA as BCM in concrete after 7 and 28 days consistently. The test results pointed out increment in hardened concrete strength while using up to $5 \%$ of WSA and $5 \%$ of RHA together because of fineness of RHA and WSA particles that occupied micropores left by other concrete ingredients while using concrete up to 5\% of WSA and 5\% of RHA together. Anwar et al. [63] corroborated this report following their assessment of the effect of ternary binder blends on the concrete microstructure. This starts declining owing to dilution influence of WSA and RHA on cement which reduces the pozzolanic reactions among the concrete ingredients. The result showed that a ternary blend of cementitious materials exhibits superior performance of concrete. In related study, the use of a combination of high calcium fly ash (HCFA), palm oil fuel ash (POFA), and rice husk ash (RHA) proved highly effective for cementitious application in soil [64]. Also, a similar result was obtained in
[65] where strength improved by using 7.5\% of fly ash along with $7.5 \%$ of silica fume in the mixture after 7 and 28 days, respectively. In [66], the strength of concrete is improved while using $5 \%$ RHA and $5 \%$ of SCBA in the mix after 7,28 , 56 , and 90 days, respectively.

3.5. Splitting Tensile Strength. The test performed on cylinder specimen made of concrete with the addition of WSA and RHA as TCM is indicated in Figure 8. The highest splitting tensile strength calculated is $2.74 \mathrm{MPa}$ and $3.52 \mathrm{MPa}$ at $5 \%$ of WSA along with 5\% of RHA, and the smallest strength is recorded as $2.05 \mathrm{MPa}$ and $2.92 \mathrm{MPa}$ while utilizing $10 \%$ of WSA along with 10\% of RHA as TCM in concrete after 7 and 28 days consistently. The test results pointed out increment in hardened concrete strength by using up to 5\% of WSA and 5\% of RHA together because of their larger specific surface areas 


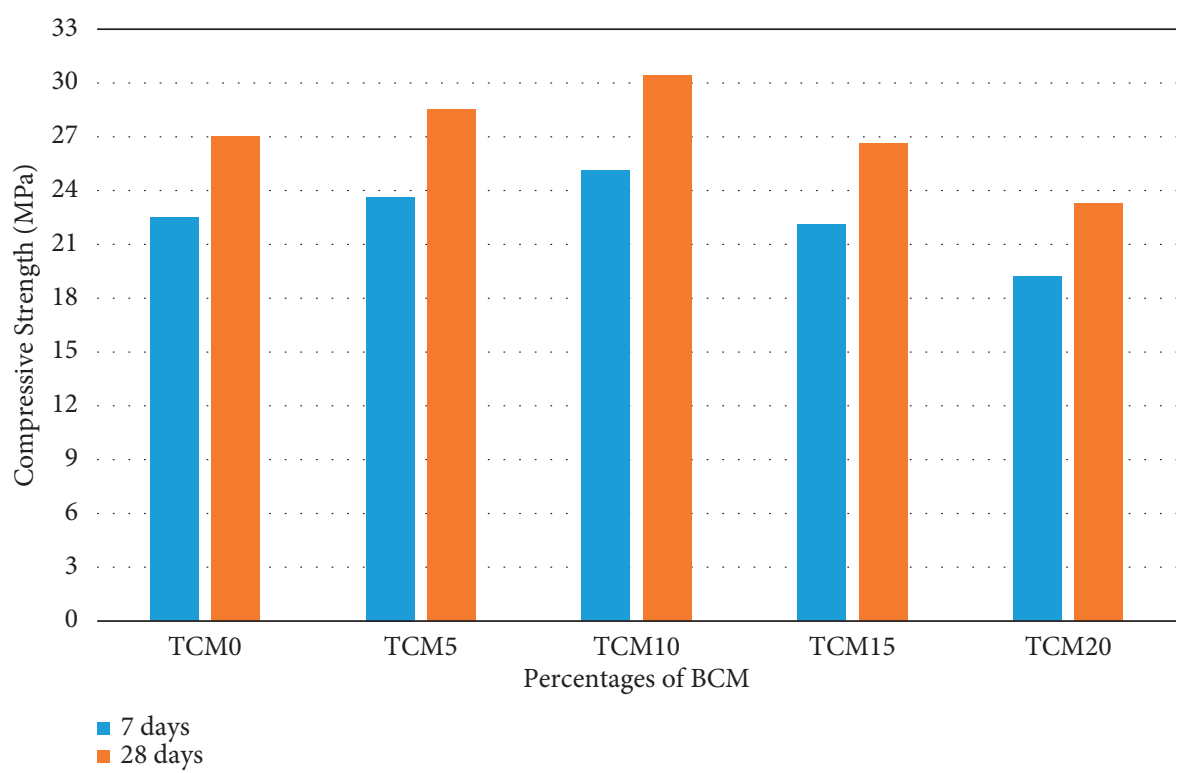

Figure 7: Compressive strength of concrete.

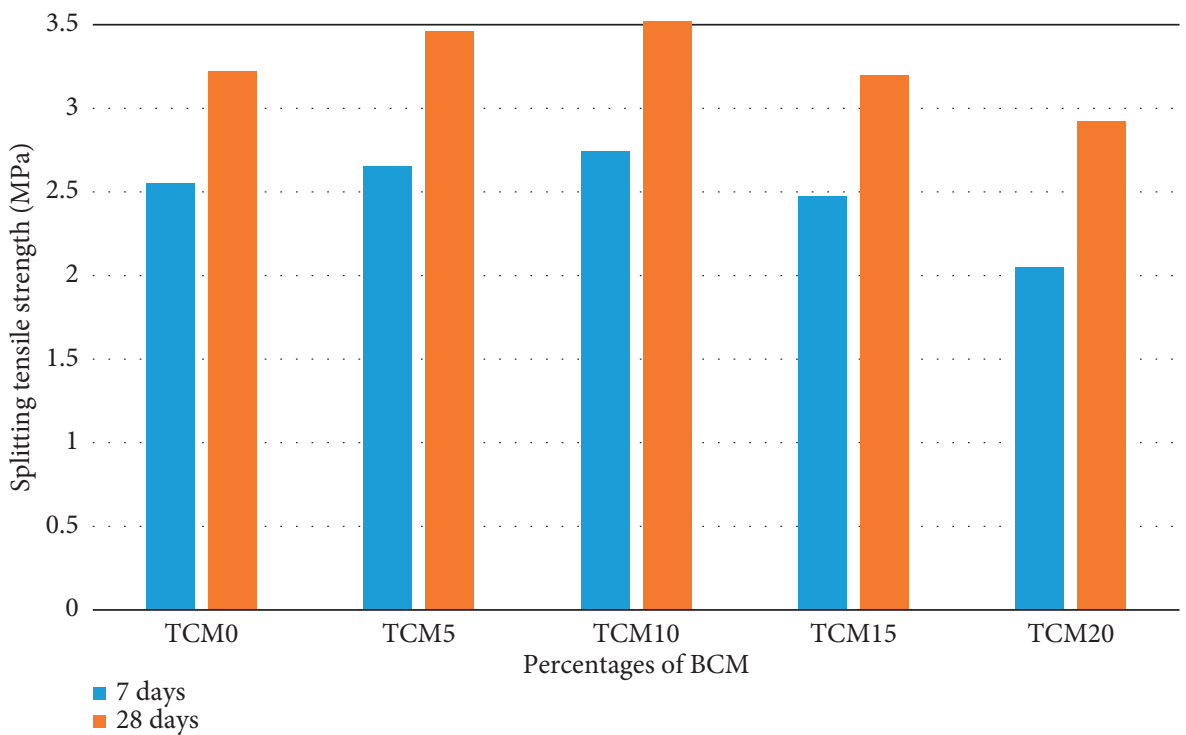

Figure 8: Splitting tensile strength of concrete.

as compared to cement, and with the further addition of WSA and RHA in the mixture, it starts declining which may be associated with low calcium hydroxide in mixture as dilution impact of WSA and RHA. A similar aspect was attained in [67] where strength improved by using $10-15 \%$ of RHA and oil palm shell ash in the mixture after 28 days, respectively. An analogous trend was shown by Kumar et al. [68] and Umamaheswari and Vigneshkumar [69]. A correlation was found between splitting tensile strength and compressive strength, as shown in Figure 9. At all ages, there is a good relationship between splitting tensile strength and compressive strength, as shown in Figure 9. The equations in Figure 9 can be used to estimate compressive strength or splitting tensile strength when one of these properties is known.
3.6. Flexural Strength of Concrete. This test is performed on the beam specimens made of concrete with the addition of WSA and RHA as TCM as indicated in Figure 10. The highest flexural strength calculated is $4.05 \mathrm{MPa}$ and $4.86 \mathrm{MPa}$ at $10 \%$ of TCM (5\% of WSA along with $5 \%$ of RHA), and the smallest strength is recorded as $3.40 \mathrm{MPa}$ and 4.0 MPa while utilizing $20 \%$ of TCM ( $10 \%$ of WSA along with $10 \%$ of RHA) in concrete after 7 and 28 days consistently. The test results showed increased flexural strength by using up to $10 \%$ of TCM ( $5 \%$ of WSA and $5 \%$ of RHA), while with the further introduction of TCM in mixture, the strength tends to decrease. This observation may be the effect of TCM dilution on PC, which leads to the fact that the transition zone of the interface is not improved and, 


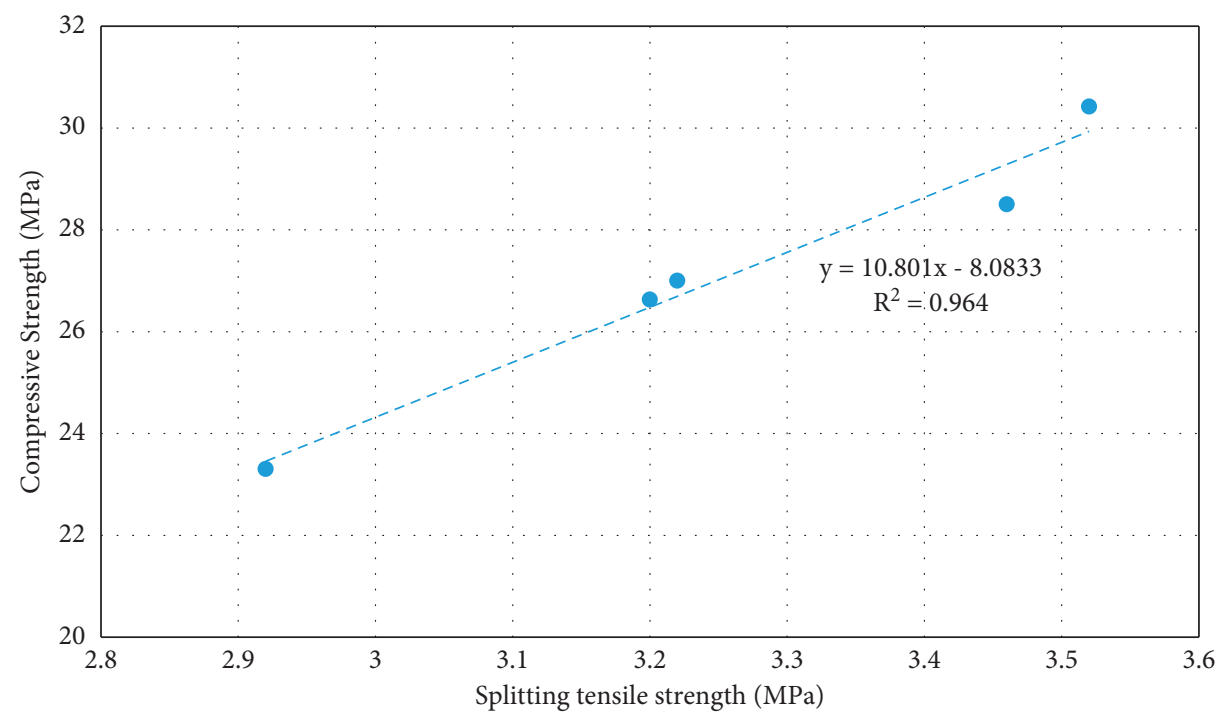

FIgURE 9: Correlations between compressive strength and splitting tensile strength at 28 days.

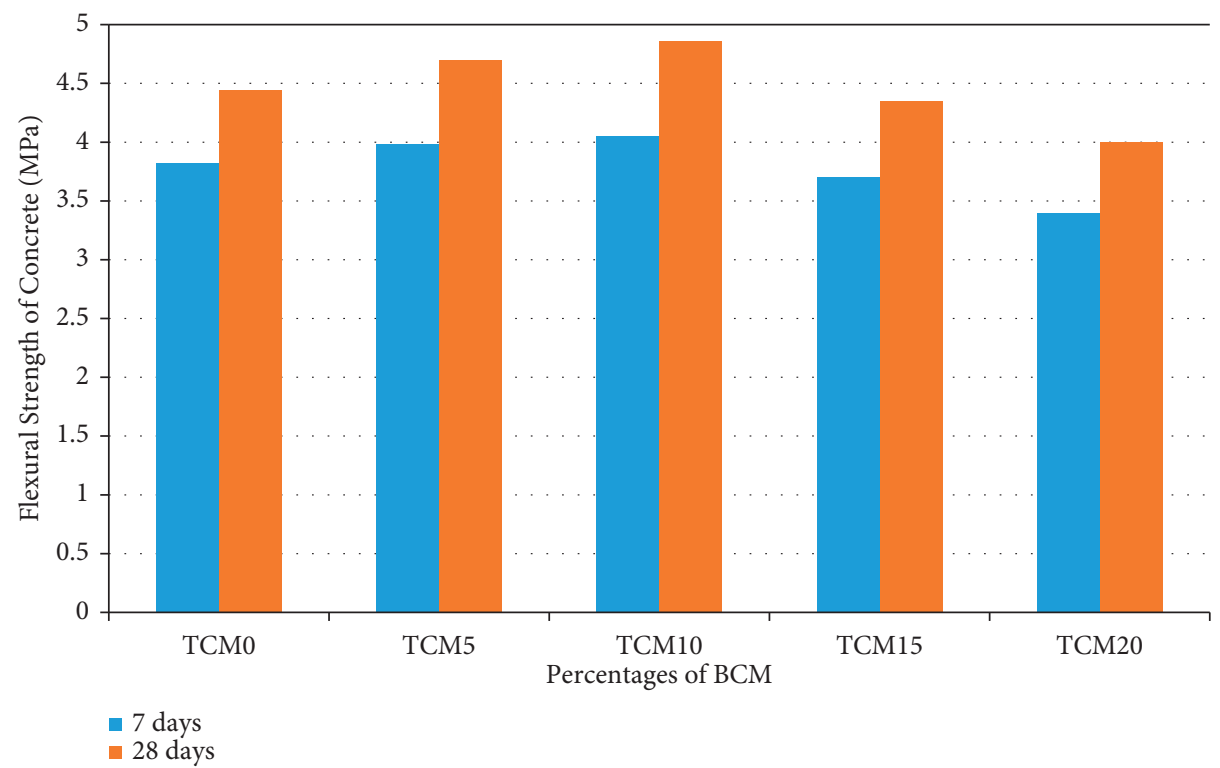

Figure 10: Flexural strength of concrete.

therefore, affects the long-term flexural strength, and with the further addition of WSA and RHA in the mixture, it starts declining which may be associated with low calcium hydroxide in mixture owing to dilution effect of WSA and RHA. A similar trend was presented in [68] where strength improved by using $10 \%$ of coconut shell ash and egg shell powder in the mixture after 28 days. A similar type of trend was presented by Umamaheswari and Vigneshkumar [69] and Mo et al. [70]. Figure 11 shows the relationship between flexural strength and compressive strength of concrete mixture. There is a strong linear relationship between these features, as can be seen in the graph. The flexural and compressive strengths, on the other hand, have a more linear relationship. Nonetheless, the two formulations in Figure 11 will be helpful in determining the properties of TCMcontaining concrete mixtures at 28 days.
3.7. Drying Shrinkage. In order to control cracks, it is essential to understand the features of concrete shrinkage and its beginning point in the construction of structures. Figure 12 describes outcomes of RHA and WSA as ternary cementitious material on the drying shrinkage of the mixture at $5,10,15,20,30,60$, and 90 days, respectively. The outcome of the research study is that the drying shrinkage of concrete is decreased with rising content of RHA and WSA as TCM in concrete. This decrement in drying shrinkage of PC pastes may be due to few causes like PC dilution by RHA and WSA, a lesser quantity of PC generating a smaller amount of shrinkage, the pozzolanic reaction of RHA and WSA with calcium hydrates $(\mathrm{CH})$ produced by $\mathrm{PC}$, and increase in capillary tension [70-72]. This observation is in agreement with [73-77] that the drying shrinkage is decreased with PC replacement by RHA with its increase in 


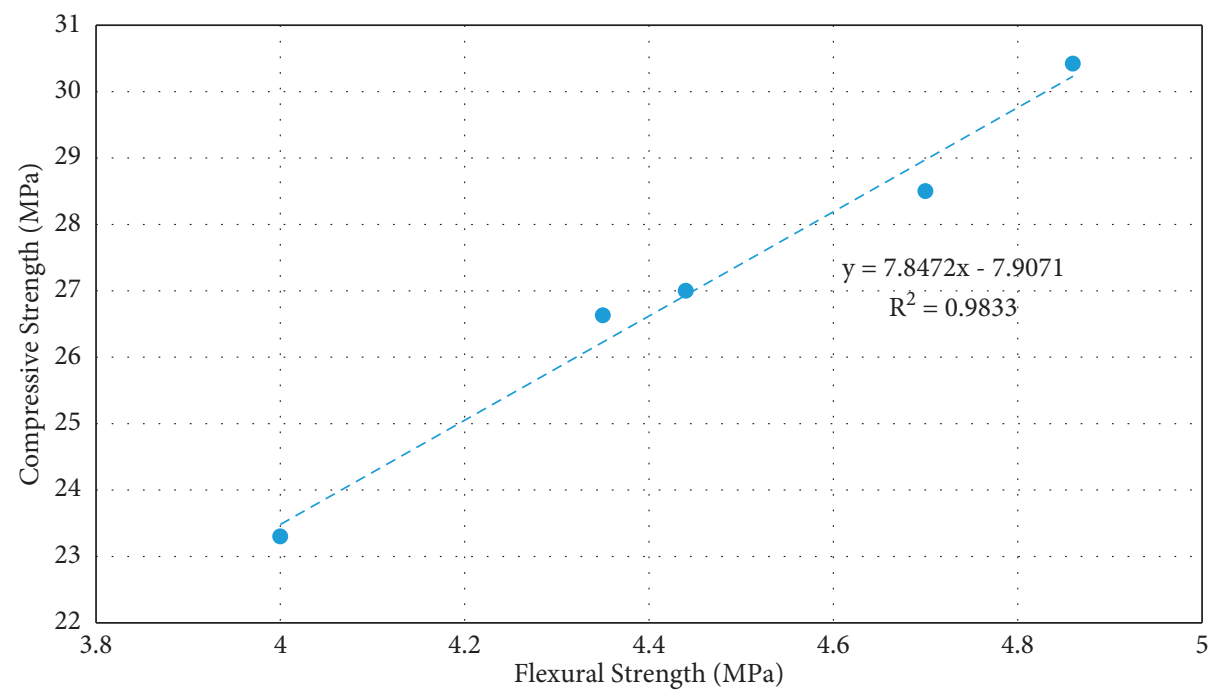

FIGURE 11: Correlations between compressive strength and flexural strength at 28 days.

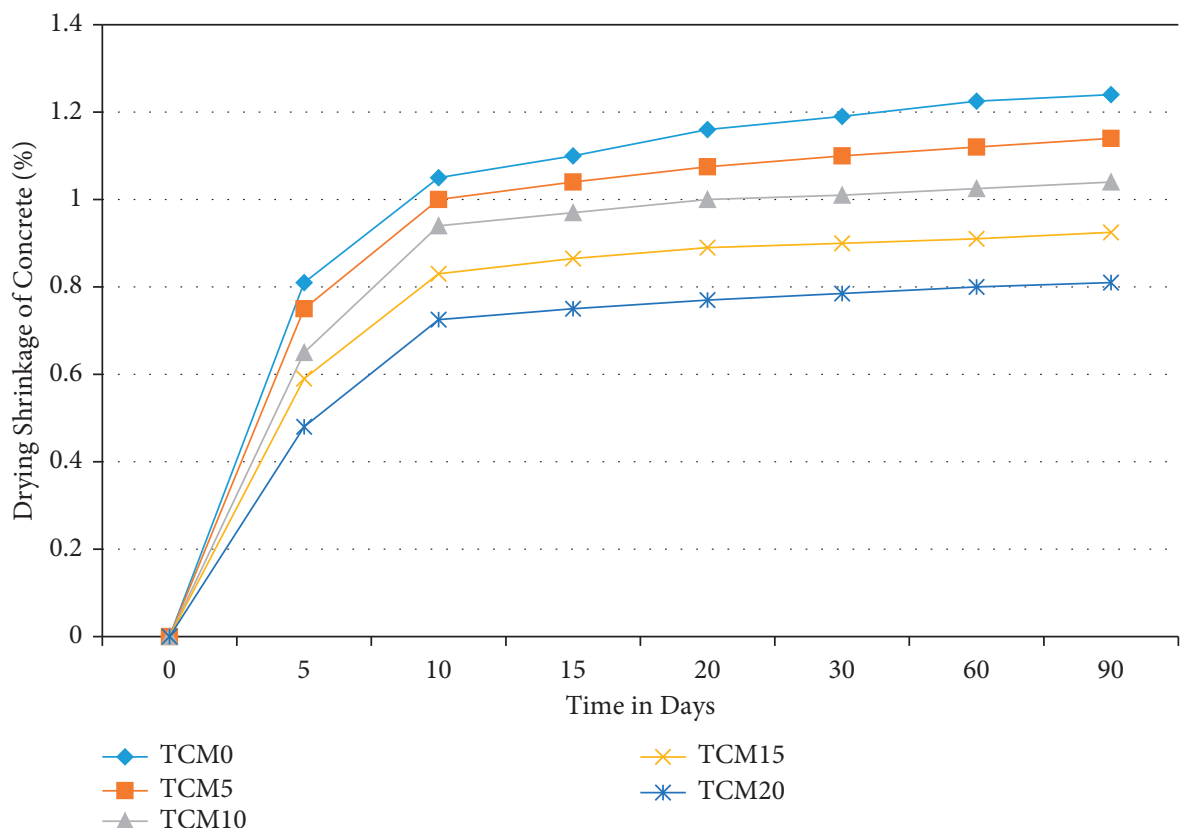

FIgURE 12: Drying shrinkage of concrete.

concrete. This decrease in drying shrinkage can be due to the RHA and WSA's finer particles, which act as a filler and plug the pores, slowing the rate of shrinkage in the concrete. On the other hand, it may be due to the size of pore and grain size improvement procedures which build up the mechanical interlocking in the transition zone. Therefore, when shrinkage is a concern, the utilization of RHA and WSA can be a part of the strategy to mitigate its effect. According to Lai et al. [78], shrinkage decreases as the amount of cement replacement material (such as ash) increases. The reduction in shrinkage is due to the concrete's wet packing density. A similar kind of research work was conducted in [79] where the drying shrinkage of concrete lowered due to replacement of PC with fly ash, WSA, and maize cob ash as a tertiary cementitious material in concrete.

\section{Conclusions}

This study determined the mechanical properties of concrete incorporating rice husk ash and wheat straw ash as a ternary cementitious material. The categories of properties explored covered the workability and hardened concrete properties. The following conclusions were drawn from the study:

(i) The slump value for all mixes reduced with increasing content of the added cementitious 
materials; thus, the control mix had a slump of $62 \mathrm{~mm}$, and the lowest slump was $24 \mathrm{~mm}$ for $10 \%$ of WSA and $10 \%$ of RHA. Similarly, the density and water absorption measured in the control mix exceeded the modified concrete samples after the 28-day curing regime.

(ii) Generally, for all mixes, the compressive strength, splitting tensile strength, and flexural strength characteristics increased with increasing curing regimes. The study showed that the strength development in the modified concrete exceeded that of the control mix. A mix with $10 \%$ supplementary cementitious material yielded the highest strength. However, the strength slightly drops as SCM content goes beyond $10 \%$.

(iii) The drying shrinkage of the concrete samples reduced as the replacement of PC with RHA and WSA increased. Overall, a concrete mix having 5\% RHA and 5\% WSA contents exhibited the best performance in terms of fresh and hardened state properties.

\section{Data Availability}

The datasets generated during the current study are available from the corresponding author upon request.

\section{Conflicts of Interest}

The authors declare that they have no conflict of interest.

\section{References}

[1] A. Manimaran, M. Somasundaram, and P. T. Ravichandran, "Experimental study on partial replacement of coarse aggregate by bamboo and fine aggregate by quarry dust in concrete," International Journal of Civil Engineering \& Technology, vol. 8, no. 8, pp. 1019-1027, 2017.

[2] S. Ghorbani, I. Taji, J. De Brito et al., "Mechanical and durability behaviour of concrete with granite waste dust as partial cement replacement under adverse exposure conditions," Construction and Building Materials, vol. 194, pp. 143-152, 2019.

[3] P. A. Shirule, A. Rahman, and R. D. Gupta, "Partial replacement of cement with marble dust powder," International Journal of Advanced Engineering Research and Studies, vol. 1, no. 3, p. 2249, 2012.

[4] J. Alex, J. Dhanalakshmi, and B. Ambedkar, "Experimental investigation on rice husk ash as cement replacement on concrete production," Construction and Building Materials, vol. 127, pp. 353-362, 2016.

[5] E. Aprianti, P. Shafigh, S. Bahri, and J. N. Farahani, "Supplementary cementitious materials origin from agricultural wastes - a review," Construction and Building Materials, vol. 74, pp. 176-187, 2015.

[6] R. Khan, A. Jabbar, I. Ahmad, W. Khan, and A Khan, Repair, Taylor \& Francis, Oxfordshire UK, 2006.

[7] P. Broomfield, "Corrosion of steel in concrete, understanding, investigation, and repair," 2006.

[8] R. R. Hussain and T. Ishida, "Critical carbonation depth for initiation of steel corrosion in fully carbonated concrete and development of electrochemical carbonation induced corrosion model," International Journal of electrochemical science, vol. 4, no. 8, pp. 1178-1195, 2009.

[9] C. I. Federation, CIF Cement Industry Environment Report, Cement Industry Federation, Forrest, Australia, 2003.

[10] S. Assefa and M. Dessalegn, "Production of lightweight concrete using corncob ash as replacement of cement in concrete," American Journal of Civil Engineering, vol. 7, no. 1, pp. 17-20, 2019.

[11] S. A. Mangi, N. Jamaluddin, M. H. Wan Ibrahim, M. Noridah, and S. Sohu, "Utilization of sawdust ash as cement replacement for the concrete production: a review," Engineering Science and Technology International Research Journal, vol. 1, no. 3, pp. 11-15, 2017.

[12] S. A. Mangi, M. W. Ibrahim, N. Jamaluddin, M. F. Arshad, and P. J. Ramadhansyah, "Effects of ground coal bottom ash on the properties of concrete," Journal of Engineering Science \& Technology, vol. 14, no. 1, pp. 338-350, 2019.

[13] A. Mangi, W. Ibrahim, N. Jamaluddin, S. Arshad, and S. Shahidan, "Effects of grinding process on the properties of the coal bottom ash and cement paste," Journal of Engineering and Technological Sciences, vol. 51, no. 1, pp. 1-13, 2019.

[14] N. Kad and M. Vinod, "Review research paper on influence of rice husk ash on the properties of concrete," International Journal of Research, vol. 2, no. 5, pp. 873-877, 2015.

[15] M. Anwar, T. Miyagawa, and M. Gaweesh, "Using rice husk ash as a cement replacement material in concrete," in Waste Management Seriesvol. 1, , pp. 671-684, Elsevier, 2000.

[16] S. D. Nagrale, H. Hajare, and P. R. Modak, "Utilization of rice husk ash," Carbon, vol. 2, no. 6, p. 42, 2012.

[17] Ologunagba, A. S. Daramola, and Daramola, "Feasibility of using rice husk ash as partial replacement for concrete," International Journal of Engineering Trends and Technology, vol. 30, no. 5, pp. 267-269, 2015.

[18] A. N. Givi, S. A. Rashid, F. N. A. Aziz, and M. A. M. Salleh, "Contribution of rice husk ash to the properties of mortar and concrete: a review," Journal of American science, vol. 6, no. 3, pp. 157-165, 2010.

[19] H. B. Mahmud, N. A. A. Hamid, and K. Y. Chin, "November. Production of high strength concrete incorporating an agricultural waste-rice husk ash," in Proceedings of the 2010 2nd International Conference on Chemical, Biological and Environmental Engineering, pp. 106-109, IEEE, Cairo, Egypt, November 2010.

[20] Le, K. Siewert, and Ludwig, "Alkali silica reaction in mortar formulated from self-compacting high performance concrete containing rice husk ash," Construction and Building Materials, vol. 88, pp. 10-19, 2015.

[21] M. H. Zhang, R. Lastra, and V. M. Malhotra, "Rice-husk ash paste and concrete: some aspects of hydration and the microstructure of the interfacial zone between the aggregate and paste," Cement and Concrete Research, vol. 26, no. 6, pp. 963-977, 1996.

[22] N. P. Hasparyk, P. J. Monteiro, and H. Carasek, "Effect of silica fume and rice husk ash on alkali-silica reaction," $M a$ terials Journal, vol. 97, no. 4, pp. 486-492, 2000.

[23] K. Sakr, "Effects of silica fume and rice husk ash on the properties of heavy weight concrete," Journal of Materials in Civil Engineering, vol. 18, no. 3, pp. 367-376, 2006.

[24] V. Sata, C. Jaturapitakkul, and K. Kiattikomol, "Influence of pozzolan from various by-product materials on mechanical properties of high-strength concrete," Construction and Building Materials, vol. 21, no. 7, pp. 1589-1598, 2007. 
[25] M. M. Tashima, C. A. Da Silva, J. L. Akasaki, and M. Beniti, "The possibility OF adding rice huskash (RHA)," vol. 2, p. 778, 2004 PRO 40: International RILEM Conference on the Use of Recycled Materials in Buildings and Structures.

[26] A. Antiohos, E. Tapali, M. Zervaki, J. Sousa-Coutinho, S. Tsimas, and V. G. Papadakis, "Low embodied energy cement containing untreated RHA: a strength development and durability study," Construction and Building Materials, vol. 49, pp. 455-463, 2013.

[27] L. Prasittisopin and D. Trejo, "Hydration and phase formation of blended cementitious systems incorporating chemically transformed rice husk ash," Cement and Concrete Composites, vol. 59, pp. 100-106, 2015.

[28] M. F. M. Zain, M. N. Islam, F. Mahmud, and M. Jamil, "Production of rice husk ash for use in concrete as a supplementary cementitious material," Construction and Building Materials, vol. 25, no. 2, pp. 798-805, 2011.

[29] R.-S. Bie, X.-F. Song, Q.-Q. Liu, X.-Y. Ji, and P. Chen, "Studies on effects of burning conditions and rice husk ash (RHA) blending amount on the mechanical behavior of cement," Cement and Concrete Composites, vol. 55, pp. 162-168, 2015.

[30] M. Akhter, "Experimental study on effect of wood ash on strength of concrete," International Research Journal of Engineering and Technology, vol. 4, no. 7, pp. 1252-1254, 2017.

[31] A. Buregyeya, S. Nwaubani, W. Schmidt, A. G. Kerali, and U. Bagampadde, "Pozzolanic and hydration properties of kamafugites and carbonatitic lavas as supplementary cementitious materials in Portland cement," African Journal of Science, Technology, Innovation and Development, vol. 10, no. 7, pp. 845-859, 2018.

[32] A. M. Nevile and J. J. Brooks, Concrete Technology, Longman Scientific and Technical, 1990.

[33] S. Rukzon, P. Chindaprasirt, and R. Mahachai, "Effect of grinding on chemical and physical properties of rice husk ash," International Journal of Minerals, Metallurgy and Materials, vol. 16, no. 2, pp. 242-247, 2009.

[34] Fao World Food Situation: http://www.fao.org/ worldfoodsituation/csdb/en/.

[35] X. Pan and Y. Sano, "Fractionation of wheat straw by atmospheric acetic acid process," Bioresource Technology, vol. 96, no. 11, pp. 1256-1263, 2005.

[36] B. Gadde, C. Menke, and R. Wassmann, "Rice straw as a renewable energy source in India, Thailand, and the Philippines: overall potential and limitations for energy contribution and greenhouse gas mitigation," Biomass and Bioenergy, vol. 33, no. 11, pp. 1532-1546, 2009.

[37] K. L. Kadam, L. H. Forrest, and W. A. Jacobson, "Rice straw as a lignocellulosic resource: collection, processing, transportation, and environmental aspects," Biomass and Bioenergy, vol. 18, no. 5, pp. 369-389, 2000.

[38] H. Kausar, M. Sariah, H. Mohd Saud, M. Zahangir Alam, and M. Razi Ismail, "Development of compatible lignocellulolytic fungal consortium for rapid composting of rice straw," International Biodeterioration \& Biodegradation, vol. 64, no. 7, pp. 594-600, 2010.

[39] A. John, Alternatives to Open-Field Burning on Paddy Farms, Vol. 18, Agricultural and Food Policy Studies Institute: Serdang, , Malaysia, 2013.

[40] W. Bank, "Decision makers' guide to municipal solid waste incineration," 2017, http://web.mit.edu/urbanupgrading/ urbanenvironment/resources/references/pdfs/

DecisionMakers.pdf.
[41] C. H. K. Lam, A. W. M. Ip, J. P. Barford, and G. McKay, "Use of incineration msw ash: a review," Sustainability, vol. 2, no. 7, pp. 1943-1968, 2010.

[42] O. Eriksson, M. Carlsson Reich, B. Frostell et al., "Municipal solid waste management from a systems perspective," Journal of Cleaner Production, vol. 13, no. 3, pp. 241-252, 2005.

[43] Y. B. Yang, V. N. Sharifi, and J. Swithenbank, "Effect of air flow rate and fuel moisture on the burning behaviours of biomass and simulated municipal solid wastes in packed beds," Fuel, vol. 83, no. 11-12, pp. 1553-1562, 2004.

[44] A. Goyal, H. Kunio, H. Ogata, M. Garg, A. M. Anwar, and M. Ashraf, "Synergic effect of wheat straw ash and rice-husk ash on strength properties of mortar," Journal of Applied Sciences, vol. 7, no. 21, pp. 3256-3261, 2007.

[45] C. Astm, 136. Standard Test Method for Sieve Analysis of fine and Coarseaggregates, American Society for Testing Materials, Pennsylvania, USA, 2005.

[46] Astm C127, Standard Method of Test for Specific Gravity and Water Absorption of Coarse Aggregate, American Society for Testing Materials, Pennsylvania, USA, 1993.

[47] Astm C128, Standard Method of Test for Specific Gravity and Water Absorption of Fine Aggregate, American Society for Testing Materials, Pennsylvania, USA, 1993.

[48] C. Astm, "29/C 29M,". Standard test," Method for Bulk Density ("Unit Weight")and Voids in Aggregate, Vol. 4, Annual Book of ASTM Standards, , Pennsylvania, USA, 1997.

[49] Bs En 12350-2, Testing Fresh concrete, Part 2: Slump-Test, BSI, London, UK, 2009.

[50] Bs 1881, Part 122, "Method, for Determination of Water Absorption”, British Standards Institution, London UK, 1983.

[51] Bs En 12390-7, Density of Hardened concrete:2000, Part 7, p. 389, British Standards Institution, London, UK, British Standards Institution, 2000.

[52] Bs En 12390-3, Testing Harden concrete. Compressive Strength of Test Specimens, BSI, London UK, 2009.

[53] Bs En 12390-6, Testing Hardened concrete. Tensile Splitting Strength of Test Specimens, BSI, London UK, 2009.

[54] B. S. En 12390-5, Testing Hardened concrete. Flexural Strength of Test Specimens, BSI, London UK, 2009.

[55] Bs Iso 1920-8, Determination of Drying Shrinkage of concrete for Samples Prepared in the Field or in the Laboratory, ISO, Geneva, Switzerland, 2009.

[56] N. M. Al-Akhras and B. A. Abu-Alfoul, "Effect of wheat straw ash on mechanical properties of autoclaved mortar," Cement and Concrete Research, vol. 32, no. 6, pp. 859-863, 2002.

[57] D. A. Adesanya and A. A. Raheem, "A study of the workability and compressive strength characteristics of corn cob ash blended cement concrete," Construction and Building Materials, vol. 23, no. 1, pp. 311-317, 2009.

[58] H. Kurama and M. Kaya, "Usage of coal combustion bottom ash in concrete mixture," Construction and Building Materials, vol. 22, no. 9, pp. 1922-1928, 2008.

[59] J. R. Ajayi, B. O. Rasheed, and O. F. Mojirade, "Exploratory assessment of strength characteristics of millet husk ash (MHA) blended cement laterized concrete," Advances in Applied Science Research, vol. 4, no. 1, pp. 452-457, 2013.

[60] M. S. Raza, R. A. I. Kunal, D. Kumar, and A. L. I. Mutahar, "Experimental study of physical, fresh-state and strength parameters of concrete incorporating wood waste ash as a cementitious material," Journal of Materials and Engineering Structures «JMES», vol. 7, no. 2, pp. 267-276, 2020.

[61] S. M. Auta, A. J. Shiwua, and T. Y. Tsado, "Compressive strength of concrete with millet husk ash (MHA) as a partial 
replacement for cement," Magazine of Civil Engineering, vol. 59, no. 7, pp. 74-79, 2015.

[62] D. Dharani and V. A. iravida Selvan, "Durability studies on concrete by using groundnut shell ash as mineral admixture," International Journal for Innovative Research in Science \& Technology, vol. 3, no. 10, pp. 168-172, 2017.

[63] M. Anwar and D. A. Emarah, "Pore structure of concrete containing ternary cementitious blends," Results in Materials, vol. 1, Article ID 100019, 2019.

[64] H. M. Jafer, W. Atherton, M. Sadique, F. Ruddock, and E. Loffill, "Development of a new ternary blended cementitious binder produced from waste materials for use in soft soil stabilisation," Journal of Cleaner Production, vol. 172, pp. 516-528, 2018.

[65] A. Kumar, N. Bheel, I. Ahmed, S. H. Rizvi, R. Kumar, and A. A. Jhatial, "Effect of silica fume and fly ash as cementitious material on hardened properties and embodied carbon of roller compacted concrete," Environmental Science and Pollution Research, pp. 1-13, 2021.

[66] S. H. Channa, S. A. Mangi, N. Bheel, F. A. Soomro, and S. H. Khahro, "Short-term analysis on the combined use of sugarcane bagasse ash and rice husk ash as supplementary cementitious material in concrete production," Environmental Science and Pollution Research, pp. 1-10, 2021.

[67] S. Foong, R. Alengaram, W. Jumaat, and G. Mo, "Enhancement of the mechanical properties of lightweight oil palm shell concrete using rice husk ash and manufactured sand," Journal of Zhejiang University - Science, vol. 16, no. 1, pp. 59-69, 2015.

[68] R. R. Kumar, R. Mahendran, S. G. Nathan, D. Sathya, and K. Thamaraikannan, "An experimental study on concrete using coconut shell ash and egg shell powder," South Asian Journal of Engineering and Technology, vol. 3, no. 7, pp. 151-161, 2017.

[69] R. Umamaheswari and M. Vigneshkumar, "Experimental study on partial replacement of cement with coconut shell ash and silica fume in concrete," Int Res J Eng Technol, vol. 5, no. 7, pp. 2175-2179, 2018.

[70] K. H. Mo, F. A. Mohd Anor, U. J. Alengaram, M. Z. Jumaat, and K. J. Rao, "Properties of metakaolin-blended oil palm shell lightweight concrete," European Journal of Environmental and Civil Engineering, vol. 22, no. 7, pp. 852-868, 2018.

[71] J. J. Brooks and M. A. Megat Johari, "Effect of metakaolin on creep and shrinkage of concrete," Cement and Concrete Composites, vol. 23, no. 6, pp. 495-502, 2001.

[72] S. Wild, J. M. Khatib, and L. J. Roose, "Chemical shrinkage and autogenous shrinkage of Portland cement-metakaolin pastes," Advances in Cement Research, vol. 10, no. 3, pp. 109-119, 1998.

[73] J. M. Kinuthia, S. Wild, B. B. Sabir, and J. Bai, "Self-compensating autogenous shrinkage in Portland cement-metakaolin-fly ash pastes," Advances in Cement Research, vol. 12, no. 1 , pp. 35-43, 2000.

[74] B. Chatveera and P. Lertwattanaruk, "Durability of conventional concretes containing black rice husk ash," Journal of Environmental Management, vol. 92, no. 1, pp. 59-66, 2011.

[75] G. A. Habeeb and M. M. Fayyadh, "Rice husk ash concrete: the effect of RHA average particle size on mechanical properties and drying shrinkage," Australian Journal of Basic and Applied Sciences, vol. 3, no. 3, pp. 1616-1622, 2009.

[76] S. I. Khassaf, A. T. Jasim, and F. K. Mahdi, "Investigation the properties of concrete containing rice husk ash to reduction the seepage in canals," International Journal of Scientific Technology Research, vol. 3, no. 4, pp. 348-354, 2014.
[77] Q. Mahmud, A. Malik, R. Kahar, E. Zain, and W. Raman, "Mechanical properties and durability of normal and water reduced high strength grade 60 concrete containing rice husk ash," Journal of Advanced concrete Technology, vol. 7, no. 1, pp. 21-30, 2009.

[78] M. H. Lai, S. A. M. Binhowimal, A. M. Griffith et al., "Shrinkage, cementitious paste volume, and wet packing density of concrete," Structural Concrete, 2020.

[79] N. Bheel, A. Awoyera, and D. Olalusi, "Engineering properties of concrete with a ternary blend of fly ash, wheat straw ash, and maize cob ash," International Journal of Engineering Research in Africa, vol. 54, pp. 43-55, 2021. 